\title{
Chapter 9 \\ Rewilding Europe: A New Strategy for an Old Continent
}

\author{
Wouter Helmer, Deli Saavedra, Magnus Sylvén and Frans Schepers
}

\begin{abstract}
The European landscape is changing and new opportunities for conservation are arising. The main driver of this change is an unprecedented shift in agricultural practices that started in the mid-twentieth century. As a result, shepherds and small-scale farmers release nearly 1 million ha of land from agriculture, each year. Although land abandonment is often seen as a major socio-economic problem, it could also be an opportunity for a new rural development based on nature and wild values. This idea can be further enhanced by the comeback of a number of iconic wildlife species, by an increased network of protected areas, by better legislation and enforcement, and a more favourable environment policy. Rewilding Europe responds to these major changes in the European landscape by ceasing this opportunity for both the European natural heritage and Europeans. The initiative aims to rewild 1 million ha of land by 2022, creating ten wildlife and wilderness areas all across Europe. Besides the ecological benefits of rewilding abandoned landscapes, wild values can create new opportunities for entrepreneurship in these areas, while a restored and preserved wildlife will attract many visitors to watch, enjoy and experience the wild. Ultimately, a large-scale shift in land use across Europe towards wilder nature and innovative ways to use this resource for employment and subsistence could be achieved, thus turning threats and problems into opportunities.
\end{abstract}

Keywords Rewilding Europe $\cdot$ Land abandonment $\cdot$ Wildlife comeback $\cdot$ Rewilding enterprise $\cdot$ Wild values $\cdot$ Key species

W. Helmer $(\varangle) \cdot$ D. Saavedra $\cdot$ M. Sylvén $\cdot$ F. Schepers

Rewilding Europe, Toernooiveld 1, 6525 Nijmegen, The Netherlands

e-mail: wouter.helmer@rewildingeurope.com

D. Saavedra

e-mail: deli.saavedra@rewildingeurope.com

M. Sylvén

e-mail: magnus.sylven@rewildingeurope.com

F. Schepers

e-mail: frans.schepers@rewildingeurope.com

H. M. Pereira, L. M. Navarro (eds.), Rewilding European Landscapes, 


\subsection{The Opportunity of Change}

Europe is changing rapidly, offering more opportunities for nature today than for the past centuries. One of the major reasons of this is an unprecedented change in land-use, a unique circumstance driven by three major forces: a strong migration of - in particular younger-people to the $\operatorname{cities}^{1}$ (EC 2008), intensification of agricultural use on the most productive soils (e.g. Pinto-Correia and Mascarenhas 1999) and, at the same time, large scale land abandonment in more remote areas (Keenleyside and Tucker 2010). Each year nearly 1 million ha of land are abandoned by shepherds and small farmers. Where land abandonment is often seen as a major socio-economic problem, it may provide an opportunity for new forms of rural development based on nature and certain valuable attributes of wild landscapes (see Chap. 1).

This opportunity is complemented by the major comeback of a number of iconic wildlife species (Deinet et al. 2013; Enserink and Vogel 2006; Kuemmerle et al. 2010; Russo 2006; and see Chaps. 4, 5, 8), supported by a growing network of protected areas (especially Natura 2000) better designed to suit multi-use criteria, with, for example, strict conservation, development, and ecotourism (e.g. Geneletti and van Duren, 2008; Zhang et al. 2013); better legislation and enforcement (Habitats, Bird and Water Directives, Bern Convention); and a more favourable policy environment (Wilderness Resolution, new EU Biodiversity Strategy); all contributing to an historic opportunity to create more space for wild nature in Europe. By reacting to these developments, European conservationists can make significant steps forward in their efforts to create a robust network of ecosystems that can sustain and improve their ecological values based on natural processes. The main challenges to the conservation of Europe's natural heritage are not so much related to where and what to protect, but how to protect and manage these often considerably large areas, and to optimise their ecological potential.

A fundamental challenge to this process exists in reinforcing the relevance, importance and value of these vast natural areas to European citizens and both urban and rural communities (Hochtl et al. 2005; Lupp et al. 2011). Over the last 10 years a growing number of initiatives all over Europe are focusing on natural processes and the reintroduction of missing keystone species (e.g. Burton 2011; Decker et al. 2010; Sandom et al. 2013) $)^{2}$ as a key conservation approach, as opposed to active human management. Because most of these, often stand-alone, projects focus on the broader trends described above, the need to combine the approach and create an opportunity for collaboration has emerged. This is now available through the European wide initiative: Rewilding Europe (Sylven et al. 2010).

\footnotetext{
${ }^{1} \mathrm{http} / /$ www.eea.europa.eu/pressroom/speeches/urbanisation-in-europe-limits-to-spatial-growth.

${ }^{2}$ For more examples, see:http://www.wildeurope.org/index.php?option=com_content\&view=article $\&$ catid $=2 \% 3$ Arestoration $\&$ id $=62 \% 3$ Aconference-pres $\&$ Itemid $=19$.
} 


\subsection{A New Vision for an Old Continent}

\section{The Initiative}

In November 2010, Rewilding Europe, a new European nature initiative was launched in Brussels. To jump-start the initiative, the initiating partners, WWF Netherlands, ARK Nature, Wild Wonders of Europe and Conservation Capital agreed only a few months later to establish the Foundation Rewilding Europe as a separate legal entity. Together with the foundation, a limited company was registered, fully owned by the foundation. In this way Rewilding Europe is able to set up innovative conservation enterprises and participate in new forms of sustainable business development related to rewilding activities.

Rewilding Europe aims to rewild 1 million ha of land by 2020 (Sylven et al. 2010), creating ten magnificent wildlife and wilderness areas to serve as inspirational examples for what can be replicated and achieved elsewhere. These ten areas should serve as benchmarks for a large-scale shift in land use across Europe towards wilder nature and new ways to use that resource for employment and self-sustainability (Schepers and Widstrand 2012). To support this, a wider European Rewilding Network is under development ${ }^{3}$ with the ultimate aim of influencing land use over a total of 10 million ha.

\section{Nominations from all over Europe}

In May 2009, the first ideas for a new European nature initiative were presented to a wide audience at the first European Wilderness Conference in Prague (Coleman and Aykroyd 2009). Organizations, governments, park managers and relevant stakeholders were invited to nominate areas to potentially be part of the initiative. In total, nearly 30 nominations were received for areas with high rewilding potential from all corners of Europe.

Out of these, five prime regions were selected to become showcases of how the Rewilding Europe vision can be put into practice (Fig. 9.1). These areas are located in Western Iberia (Portugal and Spain), the Velebit Mountains (Croatia), the Eastern Carpathians (Slovakia and Poland), the Southern Carpathians (Romania), and the Danube Delta (Romania).

By incorporating the next four rewilding areas into the initiative (Fig. 9.1), a diverse geographical representation of Europe will be achieved covering a broad array of different landscapes, from lowland river deltas to high mountains; from dehesa to tundra; from primeval beech forests to taiga; from upland river valleys to high cliffs. Each of these areas covers a minimum potential size of 100,000 ha.

\footnotetext{
${ }^{3} \mathrm{http}: / / \mathrm{www}$. rewildingeurope.com/news/articles/rewilding-europe-starts-european-rewildingnetwork/.
} 
Current Rewilding Areas:

1. Western Iberia

2. Velebit Mountains

3. Eastern Carpathians

4. Southern Carpatians

5. Danube Delta

Candidate Areas:

6. Central Apennines

7. Greater Laponia

8. Odra Delta

9. Rhodopes

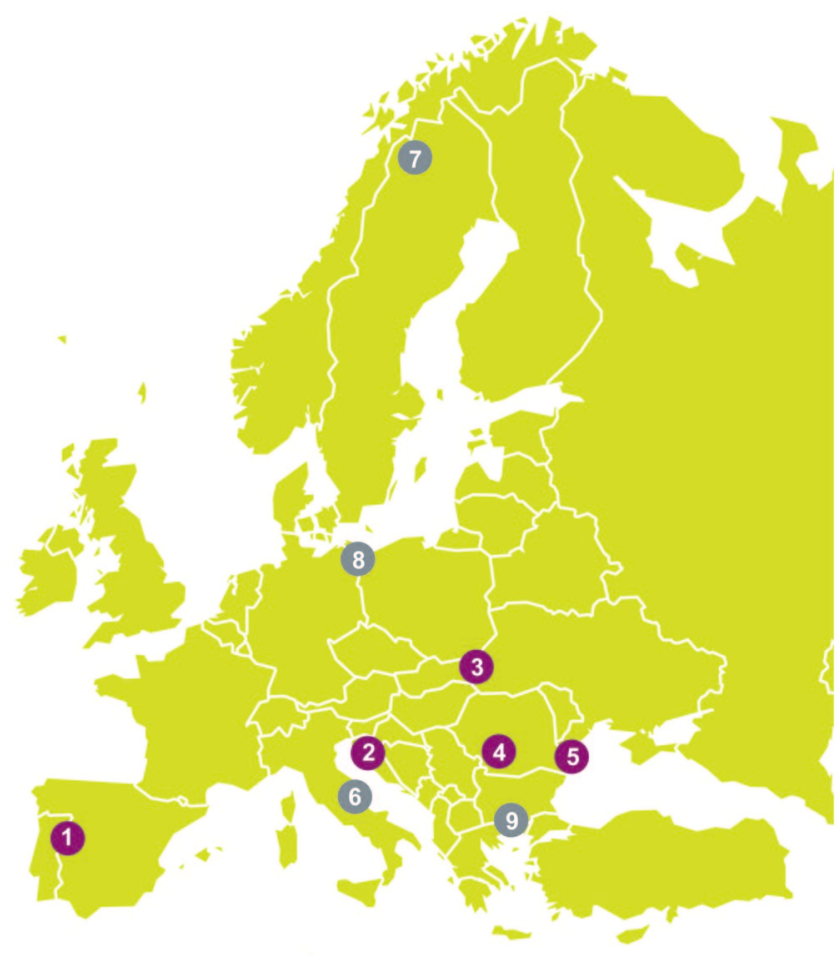

Fig. 9.1 Map of Europe showing the existing five rewilding areas (purple) and the four candidate areas (grey) in 2013

The rewilding areas are guided by three main principles: (1) Every area should host complete and naturally functioning ecosystems specific to the region with a full spectrum of native wildlife typical for the region present; (2) The areas should be embedded within the social, historical and cultural fabric of their respective region; and (3) The new land use should be based on what nature can offer and be economically viable and competitive with other alternatives. These principles were defined in order to show that Europe can indeed deal in new ways with nature, within a modern society, that gives space for wild areas, wildlife and wilderness. It is about letting nature run more of its own business - and at the same time letting people create businesses, jobs and employment from it. These attributes and opportunities are communicated by the initiative across a broad spectrum of stakeholders from the European Commission to local landowners. This is a completely new conservation vision for Europe driving the ultimate goal: a wilder Europe in the twenty-first century. 


\section{Main Objectives}

Rewilding Europe has set itself 10 clear objectives to be achieved over a 10-year period. These are applied from a central governance to local level, and include:

1. A total of at least 1 million ha $\left(10,000 \mathrm{~km}^{2}\right)$ of land will be 'rewilded' by the initiative and its partners, across 10 places covering different geographical regions of Europe, including different landscapes and habitats.

2. A substantial wildlife comeback (in particular for keystone or flagship species) will take place in the 10 rewilding areas, supported by re-introductions where appropriate or necessary, serving as the starting point for complete, functional ecosystems.

3. In each of the 10 rewilding areas, sufficient "in-situ" breeding facilities for wildlife will be established, for a variety of wildlife species that can be used for re-introductions or re-stocking of these areas.

4. Because of a growing demand for wildlife in these rewilding areas, European wildlife will develop a 'market value', providing new business opportunities for management partners, landholders, hunting associations and the like.

5. In each of the 10 rewilding areas, 'rewilding' will become a competitive form of land (and sea) use; through supporting and building of rewilding enterprises, the economic prospects of local people and/or communities will be improved.

6. Magnification of success: the 10 rewilding areas serve as inspiring examples for other areas in Europe. This should ideally lead up to 100 other 'rewilding' initiatives launched across Europe affecting a total of 10 million ha $\left(100,000 \mathrm{~km}^{2}\right)$.

7. "Wild nature \& natural processes" will be accepted and adopted as one of the main management principles for nature conservation in Europe, in particular in the larger landscapes that have a conservation status (especially the wilder, large Natura 2000 areas).

8. Through the work of Rewilding Europe, and the communication \& outreach thereof, a sense of 'Pride of the Wild' will be created among a very broad audience in Europe, who will also again be able to enjoy these wild values.

9. A science-based and practical, tailor-made monitoring system will be established to oversee progress on the objectives of Rewilding Europe, both at the central level and in the rewilding areas.

10. The concept of the 'Joy of the Wild' will have reached out to at least 350 million European citizens, using different kind of media, outdoor and indoor exhibitions, computer and mobile applications, etc.

\section{The Operating Model}

The Rewilding Europe operating model is centred on the 10 rewilding areas. There are three main components in this operating framework (Fig. 9.2). 


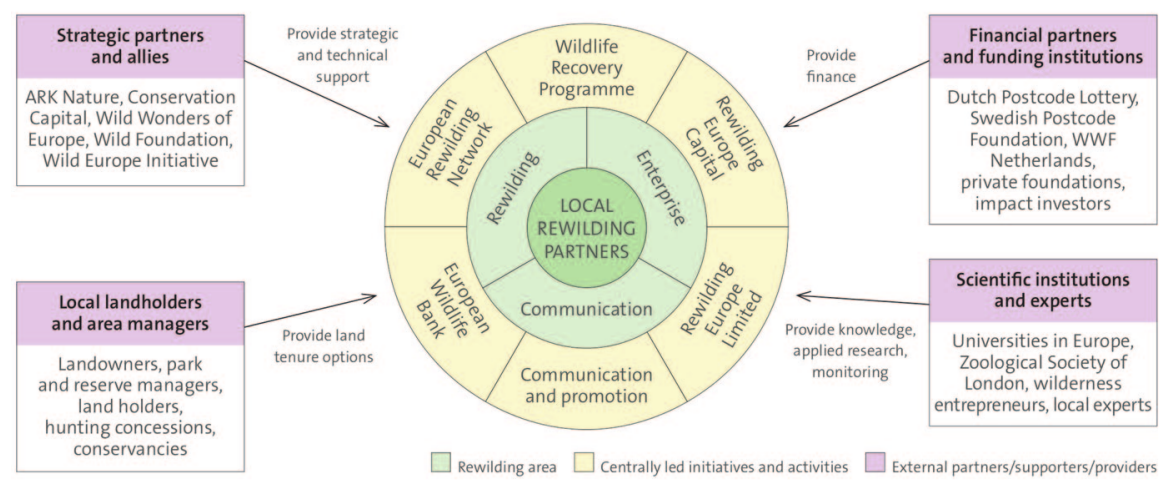

Fig. 9.2 Operating model of Rewilding Europe

The rewilding areas are in themselves carefully selected based on a number of criteria that together determine their critical success factors. Each rewilding area works in an integrated way on the three components, which are rewilding, enterprise development and communication. At the centre of this selection process are local rewilding partners who are critically important to drive and implement activities in the rewilding areas.

A central team devises the Rewilding Europe strategy and supports local teams to implement rewilding activities in the rewilding areas. The central team also launches tools and mechanisms to support programme activities, while addressing the three components listed above in an integrated way. For example it is possible that Rewilding Europe Capital provides a loan to a promising enterprise that is linked to a tauros (Bos taurus) breeding centre, while the animals are provided by the European Wildlife Bank (Fig. 9.2). The release of the animals is communicated to a wider European audience, in combination with the Aurochs book (Goderie et al. 2013) that describes the comeback of this European iconic species.

External partners and stakeholders provide support in various ways and are critical for Rewilding Europe's success and delivery. Among the strategic stakeholders are the initiating partners that provide strategic and technical support. Financial partners and funding institutions (some being also strategic partners) provide finance, such as the United Postcode Lotteries, Adessium Foundation, Liberty Wildlife Fund and new, future target groups such as impact investors and (local) business partners. Local landholders and stakeholders, such as private landowners, park and reserve managers, hunting concession owners and other landholders facilitate in securing land tenure and access. Finally scientific institutions and experts (both at a central and local level) provide scientific knowledge and background, do applied research and provide monitoring services. For example, together with Wageningen University, an international Wilderness Entrepreneurship Programme has started (see Chap. 10). Moreover, the Zoological Society of 
London, BirdLife International and other local experts are currently undertaking feasibility studies and research work (e.g. Deinet et al. 2013).

This operating model is an evolving dynamic that adapts as lessons are learnt and the landscapes evolve, however it provides an overview of how the different activities and components of Rewilding Europe are interlinked and centred around the rewilding areas.

\subsection{Applying the Model to the Rewilding Areas}

\section{General}

By the end of 2011, all five rewilding teams were contracted and began working within Rewilding Europe. Naturally, the context of setting up rewilding projects is different in each of the localities based on the socio-economic situation, local policies, and the presence of local organizations that have the capacity to provide the right leadership.

The central Rewilding Europe team provided the necessary technical support to each one of the projects. Area visits were undertaken to work with the teams and to help the projects move forward. Input was given and experience shared on all subjects related to the objectives, from bison (Bison bonasus) reintroductions, archeozoology, wildlife watching, hide construction, business plans for nature tour outfitters, land tenure alternatives (such as community conservation areas and landowner agreements), and ways to find common ground with hunting interests.

Although differing from area to area, a good start has been made and the first achievements are encouraging. It is important to emphasize that rewilding is not a quick fix, it is not about going for short-term results only. A long-term commitment and support is required in which it is essential to carefully build a good understanding and base for rewilding, generate local support for the ideas, establish partnerships with local stakeholders and build up the momentum.

\section{Rewilding}

Preparatory work in all areas involves studies, mapping, local meetings, research, opinion surveys and other activities, to create the necessary base for future success. Each of the rewilding areas started by selecting pilot sites within their larger areas, that will become the starting points for the concrete rewilding and enterprise development on the ground.

The cooperation with certain government institutions that are key for rewilding (mainly Forest and Conservation Departments) has turned out to be challenging at times, because of traditional views, frequently driven by hunting, forestry or very intense traditional/subsidized management practice interests. Although governments 
are not expected to be among the first early adopters of the rewilding concept, their role is, of course, critical for either enabling or supporting the pilot projects in the rewilding areas. By 2014, the local teams had managed to sign agreements, Letters of Intent and Memorandums of Understanding (MoUs) with several crucially important government institutions.

Another (expected) challenge for the rewilding concept has been certain traditional misunderstandings about wilderness ecology in Europe, in which the crucial ecological role of wildlife has been largely underestimated, especially when it comes to the role of the large herbivores (but see Chap. 8). In order to increase wildlife numbers, a core part of the initiative is to try to create 'breeding zones' within the rewilding areas where hunting is prohibited and wildlife numbers left to be naturally determined. In several areas good progress has been made to start working with the local hunting communities, in particular on the Portuguese side of Western Iberia and in Velebit.

Feasibility studies for reintroductions have been done or are underway for beaver (Castor fiber), red deer (Cervus elaphus), and fallow deer (Dama dama) in the Danube delta, European bison (Bison bonasus) in the Southern Carpathians and Velebit, for Balkan chamois (Rupicapra rupicapra) in Velebit, and red deer, roe deer (Capreolus capreolus), and Spanish ibex (Capra pyrenaica) in Western Iberia. These studies are required by law to permit re-stocking or re-introduction activities.

\section{Box 9.1: Major Rewilding Initiatives at the Central Level}

Wildlife Recovery Programme: a major element of the rewilding component that works with experts from all over Europe is to support natural wildlife numbers in all the rewilding areas, through planning and preparing releases or reintroductions of targeted wildlife species, in particular European bison (Vlasakker 2014), red deer, wild horse (Equus ferus caballus) (Linnartz, L \& Meissner, R. 2014), wild bovines, beaver, Iberian lynx (Lynx pardinus), Spanish ibex, chamois and others (started in 2011). This process is implemented through a number of pioneering initiatives.

European Wildlife Bank: a live asset-lending model designed to reintroduce and expand naturally grazing wild herbivore populations across Europe. This is set up as a rewilding enterprise support initiative together with ARK Nature, a partner organisation. The EWB focuses on large wild herbivores (started early 2013).

European Bison Rewilding Action Plan: a strategic action plan to create viable, wild bison populations of at least 100 individuals each in five of the rewilding areas by 2022. These animals will be sourced from existing populations e.g. zoos, nature reserves and private collections (operational in 2013).

European Rewilding Network: a network of smaller initiatives and areas in Europe where rewilding is a key target. These will be identified in addition to and in parallel with the 10 main focus rewilding areas. There are many dozens of other important initiatives over many countries, which need to be show- 
cased and communicated about as they represent other pieces of the rewilding puzzle. Connected through this network, these areas will serve as examples to exchange experiences and learn from each other. This European Rewilding Network will be strongly influential in order to create a real European movement working for rewilding all over the continent (started in 2013).

The Tauros programme: an initiative to breed back an animal that as closely as possible resembles the original wild bovine species that once roamed all across Europe, and re-introduce them as wild functional species in European ecosystems. The aurochs went extinct in 1627 , but its DNA is still very much alive, although spread between a few primitive cattle breeds which are now used for the Tauros programme. The goal is to breed significant numbers of these animals (for the time called Tauros) that can start to live in free and social herds in at least five rewilding areas by 2020 . This is done in partnership with the Taurus Foundation.

\section{Communication}

Good progress was made in promotion for Rewilding Europe as a new initiative, to several of the main target audiences. Social media, an AV-show trailer and printed materials were developed. Following the initial publishing of the major GEO cover story "Europa Wird Wilder" 4 " in Germany, a further 11 special country editions published the story in 2012. Feature articles were published in leading newspapers all over Europe and in 'The New Yorker'. Swedish, Dutch, Spanish and Portuguese national TV reported from the initiative and the first activities in the rewilding areas. Major outreach was created through the outdoor exhibitions in European capitals of which the one in Madrid reached around 104 million people through mass media coverage in the Spanish-speaking world. As a result of this, "rewilding" is now a widely understood phrase used more and more in all various contexts and translated into several languages.

A communication training was organized in the Netherlands in spring 2012, which was attended by all the local rewilding teams. At that level great achievements have been made, especially in Western Iberia, Velebit and the Eastern Carpathians, with the local teams trying out several different methods that range from opinion surveys, magazine publishing, film making, local fairs, local stakeholder meetings as well as meetings with ministers and serious media PR work around the outdoor exhibitions.

Professional photo assignments have been carried out in the five first rewilding areas, including documentations of the first animal releases done in Western Iberia and Southern Carpathians. This means that there is now a good stock of high quality imagery available from these areas that is widely used for all kinds of communication and promotion. The quality of the image resources and the way this footage is used are a significant part of what makes the initiative stand out from the crowd.

\footnotetext{
4 "Europe is wild" in German.
} 
The development of tangible local visions for each rewilding area was given a high priority. Part of that focus led to the start of the production of artist's impressions of the envisioned future landscapes, one for each area.

\section{Enterprise Development}

The enterprise development work has made good progress in preparing fertile ground for the development of businesses, both at the central level and the rewilding area level (with a focus on Western Iberia and Velebit).

The enterprise team has worked to develop a rewilding business-financing instrument called Rewilding Europe Capital (REC), a revolving financing facility funded by philanthropic capital and owned by Rewilding Europe. REC's initial goal is to provide small, but often crucially important loans to promising businesses in the rewilding areas (starting 2013) that can generate meaningful rewilding outputs. Furthermore a business proposal has been developed for a European Safari Company. In cooperation with experienced travel organizations, this company will develop a network of seasonal camps, supported by wildlife hides, fly camps, and a range of nature and wildlife based guided activities.

Development of relevant businesses goes hand in hand with the rewilding work (see Chap. 10). In both Western Iberia and Velebit extensive explorations were done to identify existing and potential businesses that could potentially leverage rewilding outputs (directly and indirectly). This work produced a list of more than 40 potential businesses and business ideas to support and help develop. A shortlist of the most promising and meaningful businesses was selected to engage further, including tourism lodges, adventure trails, tented camps, tourism operators and relevant hunting operators.

\subsection{First Results in the Rewilding Areas}

Although Rewilding Europe is only 3 years on the way, the results in the first five rewilding areas are quite promising (Table 9.1).

\section{Western Iberia: Ancient Dehesa and Montado Landscapes}

The Iberian Peninsula, with some of the earliest human settlements in Europe, is home to some of the most ancient cultural landscapes of the continent. One typical example is the Spanish "Dehesa" or the Portuguese "Montado", traditional wood pastures which date back to the middle ages (Fig. 9.3). The savannah-like appearance shaped by large grazers, especially cattle, is today home to some of the rarest animal species of Europe, such as the Spanish Imperial Eagle and the Iberian Lynx, 
Table 9.1 Preliminary results in the first five rewilding areas for the 2012-2013 period, summarizing the main results per area, regarding the three components of the operating model: rewilding, communication and enterprise development

\begin{tabular}{|c|c|c|c|}
\hline & Rewilding & Communication & $\begin{array}{l}\text { Enterprise } \\
\text { development }\end{array}$ \\
\hline \multirow[t]{5}{*}{ Western Iberia } & $\begin{array}{l}\text { Land stewardship } \\
\text { agreements on more } \\
\text { than } 6000 \text { ha signed }\end{array}$ & $\begin{array}{l}\text { Three new wildlife } \\
\text { watching hides }\end{array}$ & $\begin{array}{l}\text { Network of local } \\
\text { entrepreneurs set up }\end{array}$ \\
\hline & $\begin{array}{l}\text { Purchase of } 200 \text { ha in } \\
\text { Portugal }\end{array}$ & $\begin{array}{l}\text { Rewilding seminar } \\
\text { organized }\end{array}$ & $\begin{array}{l}\text { Agreements on } \\
\text { advertising with } 10 \\
\text { tour operators }\end{array}$ \\
\hline & $\begin{array}{l}\text { Feasibility study on } \\
\text { red deer, roe deer and } \\
\text { ibex }\end{array}$ & $\begin{array}{l}\text { Rewilding brochure } \\
\text { prepared }\end{array}$ & $\begin{array}{l}\text { Building of } \\
\text { guesthouse ( } 8 \text { beds) } \\
\text { at Campanarios }\end{array}$ \\
\hline & \multirow[t]{2}{*}{$\begin{array}{l}\text { Release of first herds } \\
\text { of horses and tauros }\end{array}$} & \multirow[t]{2}{*}{$\begin{array}{l}\text { Biological station/visi- } \\
\text { tor center completed in } \\
\text { Campanarios }\end{array}$} & $\begin{array}{l}\text { Support of a B\&B on } \\
\text { the Portuguese side }\end{array}$ \\
\hline & & & $\begin{array}{l}\text { Business proposition: } \\
\text { Faia Brava camp }\end{array}$ \\
\hline \multirow[t]{5}{*}{$\begin{array}{l}\text { Eastern } \\
\text { Carpathians }\end{array}$} & $\begin{array}{l}\text { Study on natural } \\
\text { grazing by wild-living } \\
\text { horses completed }\end{array}$ & $\begin{array}{l}\text { Film documentary } \\
\text { about 'the wolf } \\
\text { mountains' }\end{array}$ & $\begin{array}{l}\text { Set up of an ecotour- } \\
\text { ism and wildlife travel } \\
\text { agency }\end{array}$ \\
\hline & \multirow[t]{4}{*}{$\begin{array}{l}\text { Campaign to halt the } \\
\text { killing of wolves }\end{array}$} & $\begin{array}{l}\text { Production of "Bieszc- } \\
\text { zadnik" magazine }\end{array}$ & $\begin{array}{l}\text { Selection and training } \\
\text { of nature guides }\end{array}$ \\
\hline & & $\begin{array}{l}\text { Establishment of walk- } \\
\text { ing trails with wildlife } \\
\text { watching sites }\end{array}$ & \multirow[t]{3}{*}{$\begin{array}{l}\text { Development of } \\
\text { ecotourism packages }\end{array}$} \\
\hline & & $\begin{array}{l}\text { Launch of educational } \\
\text { geo-cache trail }\end{array}$ & \\
\hline & & $\begin{array}{l}\text { Public opinion survey } \\
\text { on rewilding and } \\
\text { wilderness protection }\end{array}$ & \\
\hline \multirow[t]{4}{*}{ Velebit Mountains } & $\begin{array}{l}\text { Study on ecologi- } \\
\text { cal role bark beetle } \\
\text { completed }\end{array}$ & $\begin{array}{l}\text { Seminar with local } \\
\text { entrepreneurs on wild- } \\
\text { life watching, breeding } \\
\text { and no-hunting zones }\end{array}$ & $\begin{array}{l}\text { Ministry of tourism } \\
\text { supports wildlife } \\
\text { watching as a key } \\
\text { economic activity }\end{array}$ \\
\hline & $\begin{array}{l}\text { Archaeozoological } \\
\text { study completed as } \\
\text { input for reintroduc- } \\
\text { tion missing key } \\
\text { species }\end{array}$ & \multirow[t]{3}{*}{$\begin{array}{l}\text { Preparation of an } \\
\text { outdoor exhibition in } \\
\text { Zadar }\end{array}$} & \multirow[t]{3}{*}{$\begin{array}{l}\text { Support of a lodge, } \\
\text { near the bison } \\
\text { breeding center }\end{array}$} \\
\hline & $\begin{array}{l}\text { Freshwater study } \\
\text { completed }\end{array}$ & & \\
\hline & $\begin{array}{l}\text { Preparation of breed- } \\
\text { ing centers for bison, } \\
\text { tauros and free living } \\
\text { horses }\end{array}$ & & \\
\hline
\end{tabular}


Table 9.1 (continued)

\begin{tabular}{|c|c|c|c|}
\hline & Rewilding & Communication & $\begin{array}{l}\text { Enterprise } \\
\text { development }\end{array}$ \\
\hline \multirow[t]{4}{*}{$\begin{array}{l}\text { Southern } \\
\text { Carpathians }\end{array}$} & $\begin{array}{l}\text { Preliminary inven- } \\
\text { tory of pristine forests } \\
\text { in Tarcu mountains } \\
\text { and request for their } \\
\text { protection }\end{array}$ & \multirow[t]{4}{*}{$\begin{array}{l}\text { Establishment of a } \\
\text { technical wilderness } \\
\text { working group with } \\
\text { the directors and } \\
\text { biologists of protected } \\
\text { areas }\end{array}$} & \multirow[t]{4}{*}{$\begin{array}{l}\text { Meeting with local } \\
\text { entrepreneurs to } \\
\text { explore first ideas for } \\
\text { business opportunities }\end{array}$} \\
\hline & $\begin{array}{l}\text { Feasibility study of } \\
\text { re-introduction of } \\
\text { European bison carried } \\
\text { out and preparations } \\
\text { for a breeding center } \\
\text { in Tarcu mountains }\end{array}$ & & \\
\hline & $\begin{array}{l}\text { Guidelines for } \\
\text { management of forest } \\
\text { reserve areas with bark } \\
\text { beetle outbreaks }\end{array}$ & & \\
\hline & $\begin{array}{l}\text { First agreement on a } \\
\text { small no-hunting zone } \\
\text { around the bison area }\end{array}$ & & \\
\hline \multirow[t]{2}{*}{ Danube Delta } & $\begin{array}{l}\text { Feasibility studies for } \\
\text { the reintroduction of } \\
\text { beaver (finished) and } \\
\text { deer (draft) }\end{array}$ & $\begin{array}{l}\text { HD video footage of } \\
\text { the delta collected }\end{array}$ & $\begin{array}{l}\text { Inventory of the exist- } \\
\text { ing local businesses }\end{array}$ \\
\hline & $\begin{array}{l}\text { MoU with Danube } \\
\text { Delta Biosphere } \\
\text { Reserve Authority } \\
\text { (DDBRA) about } \\
\text { rewilding }\end{array}$ & $\begin{array}{l}\text { Underwater pho- } \\
\text { tographic mission } \\
\text { executed }\end{array}$ & $\begin{array}{l}\text { Preparations to set } \\
\text { up a community } \\
\text { conservancy }\end{array}$ \\
\hline
\end{tabular}

the most endangered feline in the world. These species have together with their favourite prey, the European rabbit (Oryctolagus cuniculus), decreased alarmingly in numbers during the last century and just only recently begun to come back slowly (Deinet et al. 2013).

Western Iberia is a bit of a frontrunner at this stage. This is mainly due to the fact that the two partner NGOs (Fundación Naturaleza y Hombre in Spain and Associação Transumançia Natureza in Portugal) owned land approximates 1300 ha, which make up the Campanarios de Azaba and Faia Brava nature reserves. These two areas are pilot sites from which the rewilding process is starting and taking shape.

Both NGOs are adopting emerging rewilding concepts and activities transitioning from traditional ways of subsidized biodiversity conservation, over to rewilding approaches and rewilding enterprise development. For example in the reserves trees were previously being planted and now large herbivores are being introduced to stimulate the natural vegetation development. 


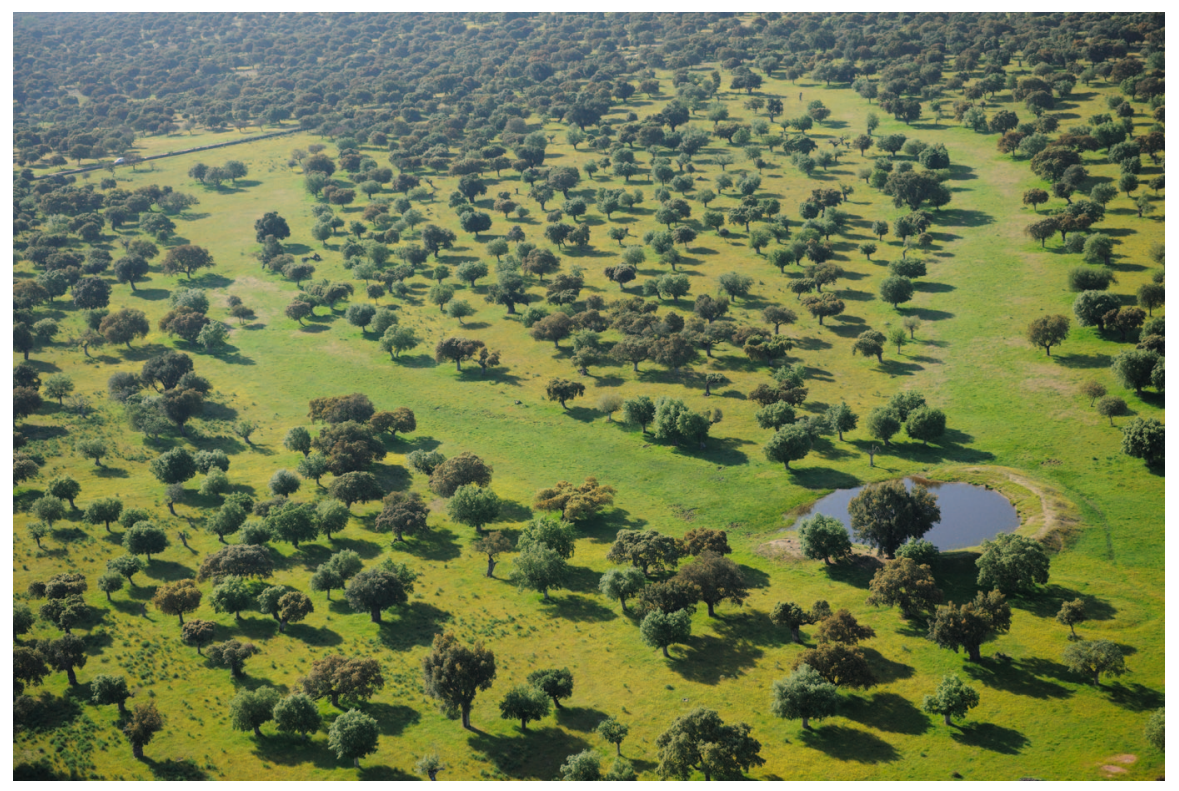

Fig. 9.3 Dehesa/montado landscape in Western Iberia. (Photo credit: Staffan Widstrand/Rewilding Europe)

Regarding the signed land stewardship agreements, 2852 ha are with direct management rights for the partner NGO's and 3471 ha without. With the release of tens of primitive Retuerta and Garrano horses and with Sayaguesa and Maronesa cattle as part of a Tauros breeding programme, natural grazing has started in the two reserves. A network of local entrepreneurs is set up to become part of the "European Safari Company" in association with an international wildlife/ nature tour operator.

\section{Velebit Mountains: The Wild West of the Adriatic Coast}

Velebit is situated on the Adriatic coast of Croatia. This limestone mountain chain is $145 \mathrm{~km}$ long from north to south, and lies parallel to the coast (Fig. 9.4). Following a cross section from the crystal waters of the Adriatic in the west, it rapidly rises to $1757 \mathrm{~m}$, and then phases out into a higher-level plateau towards the east. The area hosts an extraordinary diversity of different habitats, from barren Mediterranean landscapes at sea level, a large network of spectacular caves, to almost boreal systems at higher altitudes. This has led to the establishment of the two Paklenica \& Northern Velebit National Parks as well as the Velebit Nature Park. Together the three areas occupy more than 220,000 ha. The area is declared a UNESCO Man and Biosphere Reserve and has been included in the UNESCO Tentative List of World Heritage Sites. Inside the Nature Park and outside the protected areas in the 


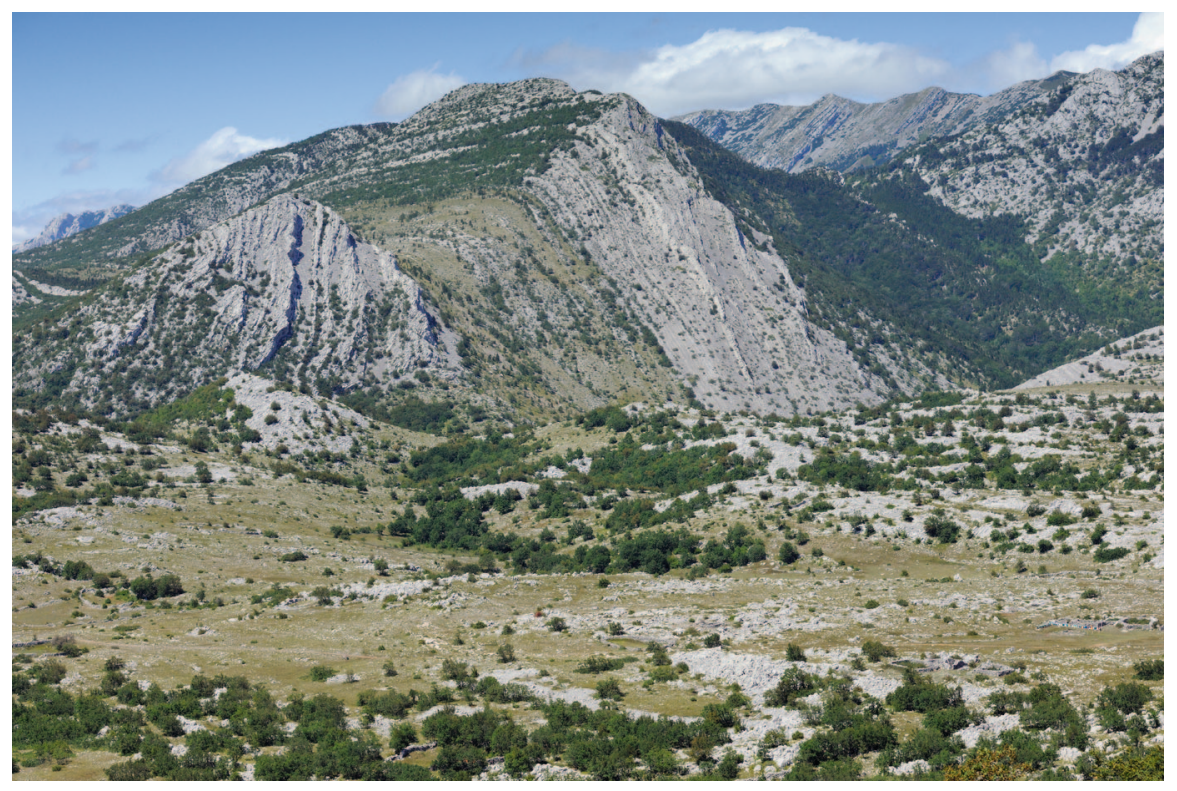

Fig. 9.4 Limestone peaks in the Velebit mountains. (Photo credit: Staffan Widstrand/Rewilding Europe)

south and west, there are very promising areas for rewilding, consisting mainly of abandoned farmland and grazing lands.

Lobby and advocacy at government level for rewilding, by the local partner WWF in Croatia, has generated genuine interest, however due to changes in government composition and policies, this interest is difficult to consolidate (e.g. revisions in hunting legislation are postponed by the parliament). Due to very active networking on the ground, a lot of promising contacts with local entrepreneurs and hunting associations have been made.

The study on bark beetle (Ips typographus) emphasizes the importance of this species in opening up forests as a key natural process in the area. The archaeozoological study on the historical presence of larger mammals, proved among others the existence of ibex (Capra ibex) in Velebit. Because the availability of water is a key limiting factor in these limestone mountains, a freshwater study was executed to map water resources for establishing natural wildlife densities in the area. An overview of the (19) existing hunting concessions has identified opportunities for creating large breeding zones and negotiations have started with several concessionaires. Finally a successful seminar was held with local entrepreneurs focusing on wildlife breeding in two places and wildlife watching in combination with the creation of breeding sites. 


\section{Eastern Carpathians: One of Europe's Top Wildlife Areas}

The Eastern Carpathians border an area between Poland and Slovakia, forming one of the wildest corners of Europe including vast, extensive forests with untamed rivers, low undulating mountains with scattered alpine meadows, and pockets of old-growth forests (Fig. 9.5). Here, one of Europe's largest wild-living populations of bison lives side by side with red deer, roe deer, wild boar (Sus scrofa), lynx (Lynx lynx), wolves (Canis lupus), bears (Ursus arctos), beavers, and otters (Lutra lutra). Few other regions of the continent have more protected areas than the Eastern Carpathians - in total around half a million ha of national parks, biosphere reserves, forest reserves, landscape parks, nature parks and Natura 2000 sites. However there is still a lot to improve on the protection of old growth forests, natural wildlife numbers and the development of a wilderness based economy.

A feasibility study shows that the Eastern Carpathians rewilding area provides huge rewilding opportunities on both the Slovakian and Polish side. This mainly focuses on trans-boundary wilderness management of migratory species including large herbivores and carnivores between the two countries. However, the level of commitment from key local stakeholders to work on rewilding is still unclear today. The first year of the project was used to create a base for a rewilding perspective with the general public. A public opinion survey on both sides of the border showed major support for the concept of wilderness protection and rewilding, thereby creating new economic opportunities.

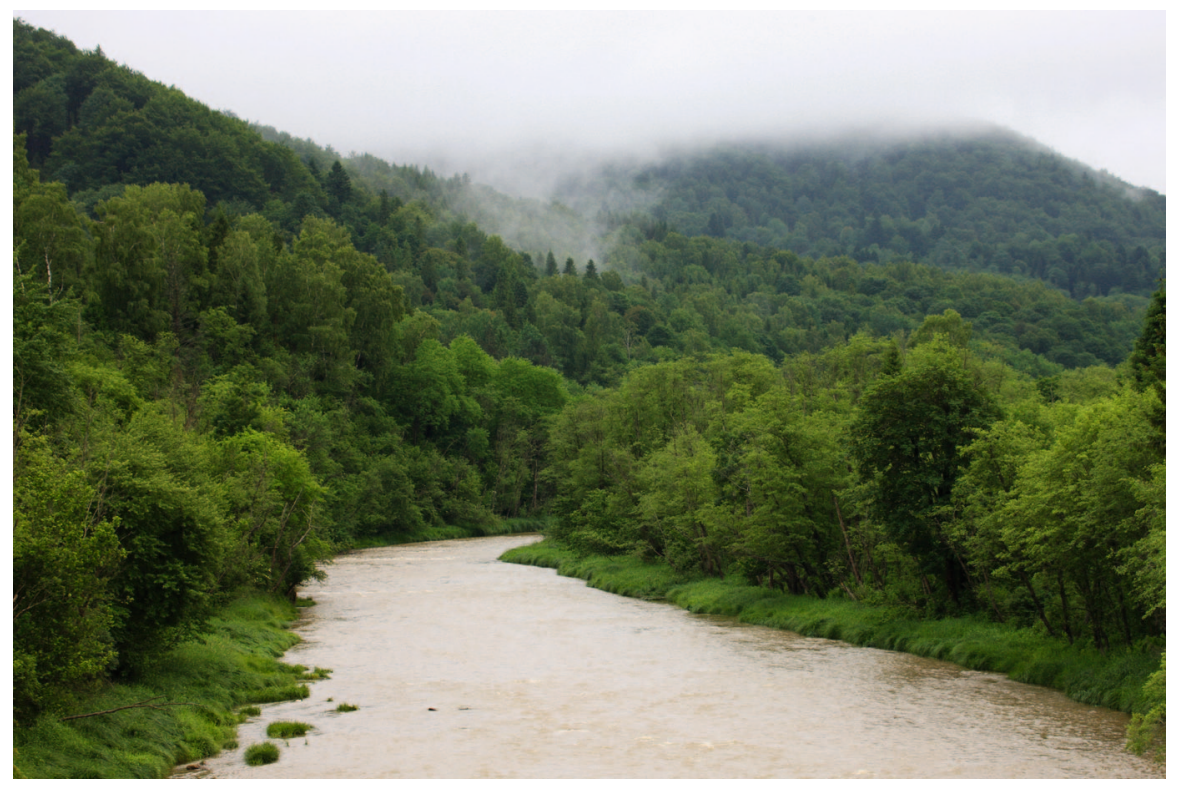

Fig. 9.5 Extensive forest with untamed rivers - the San river in Eastern Carpathians. (Photo credit: Grzegorz Leśniewski/Wild Wonders of Europe) 
The two local partner organizations (WOLF in Slovakia and the Carpathian Wildlife Foundation in Poland) put most of their energy in campaigns for rewilding and wilderness protection. Thus the starting up of pilots on the ground is lagging behind. WOLF significantly contributed to prevent an amendment to the Game Act, which would have extremely threatened herbivores and large carnivores in the Eastern Carpathians. They also achieved that selective trapping of carnivores will not be allowed. Though the legal limit in Slovakia is set to 130 killings of wolfs per year, 150 were killed in 2012, a third of which in the rewilding area. The local partner, WOLF, has been running a campaign to halt these killings, using petitions sent directly to the European Commission.

\section{Southern Carpathians: A Wilderness Arc at the Heart of Europe}

At the southern end of the Carpathian Mountains in Romania, an initiative is underway to create one of Europe's largest wilderness landscapes south of the Arctic Circle. With a backbone of more than 1 million ha of protected areas already in place, large intact forests, a high concentration of biodiversity, un-fragmented landscapes, wild rivers, and large mosaic landscapes still kept open by small scale farming practices, there is a unique opportunity to realise this vision.

The starting point is an area around the Tarcu Mountains Natura 2000 Site, with connections to the Domogled-Valea Cernei National Park, and the Retezat National Park, which together cover around 200,000 ha. The area includes a wide variety of ecosystems - alpine meadows and grasslands, old beech and fir forests, steep cliff formations, and undulating mosaic landscapes with open grasslands intersected by woodlands (Fig. 9.6). However, the numbers of large carnivores and herbivores are depressingly low and, due to poisoning, most scavengers and all vultures are gone. Patches of virgin forest are still threatened by illegal logging.

During the first year, the Southern Carpathians has concentrated on stakeholder meetings, feasibility studies, GIS mapping and planning, and creating a support base for the rewilding concept in the project area through a series of meetings with local people.

The rewilding area is part of the (larger) South Western Carpathians Wilderness Area project ${ }^{5}$, run by WWF Romania and covering 11 Protected Areas and the present rewilding area itself, which is promising for further expansion over time of the rewilding activities.

A preliminary inventory of pristine forests areas has been performed in the Tarcu Mountains N2000 area and a request was made to decision makers for their protection. An agreement was reached with the Romanian government on criteria for identification and inclusion of pristine forests in stricter protection status (Ministerial Order). The guidelines for management of forest reserve areas with bark beetle

\footnotetext{
${ }^{5} \mathrm{http}: / /$ www.erweiterungsbeitrag.admin.ch/en/Home/Projekte/Projekt_Detailansicht?projectinfo $\mathrm{ID}=222831$.
} 


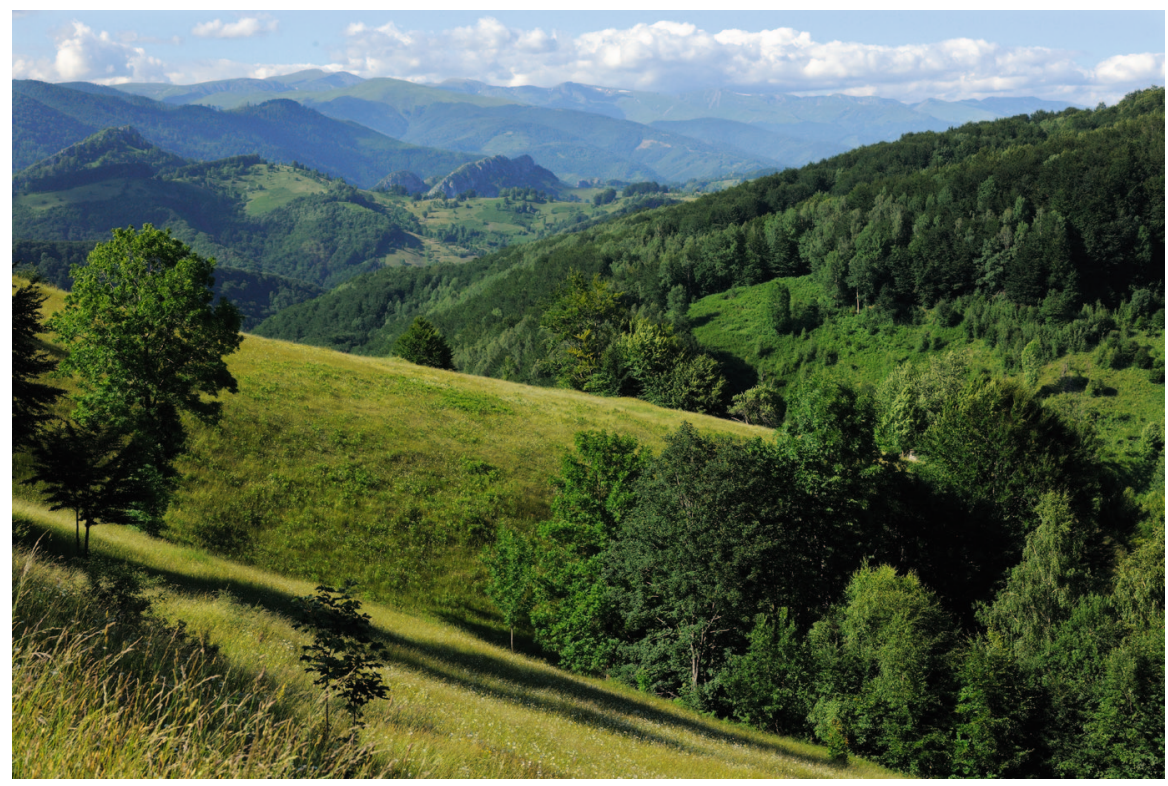

Fig. 9.6 Alpine meadows and old growth forests in the Southern Carpathians. (Photo credit: Staffan Widstrand/Rewilding Europe)

outbreaks were developed and submitted to the Romanian government, to promote as a key natural process and non-intervention policy. Managers of hunting areas, game and forest managers were approached about initiating non-intervention management measures (e.g. creation of no-hunting areas). Finally a feasibility study of re-introduction of European bison was carried out, with the most suitable area identified and agreed for re-introduction in the Tarcu Mountain Natura 2000 site, to be executed in 2014 .

\section{Danube Delta: Europe's Unrivalled Wetland}

The Danube Delta on the border between Romania and Ukraine is outstanding in Europe - due to its size (over 600,000 ha), intact river dynamics, unexploited coastline (shaped by the Danube River and the Black Sea together), wide horizons and large-scale landscapes without significant infrastructure (Fig. 9.7). It also has the largest reed beds in the world, in addition to millions of nesting and migrating birds, many of them rare and some even globally endangered. However, some of the key wildlife species are still missing, such as wolf, red deer and beaver. Due to poisoning, numbers of species like black kites (Milvus migrans), golden jackals (Canis aureus) or vultures are extremely low. Apart from legal enforcement, giving value to these species as part of the wildlife watching economy should stimulate social control to avoid these illegal practices. 


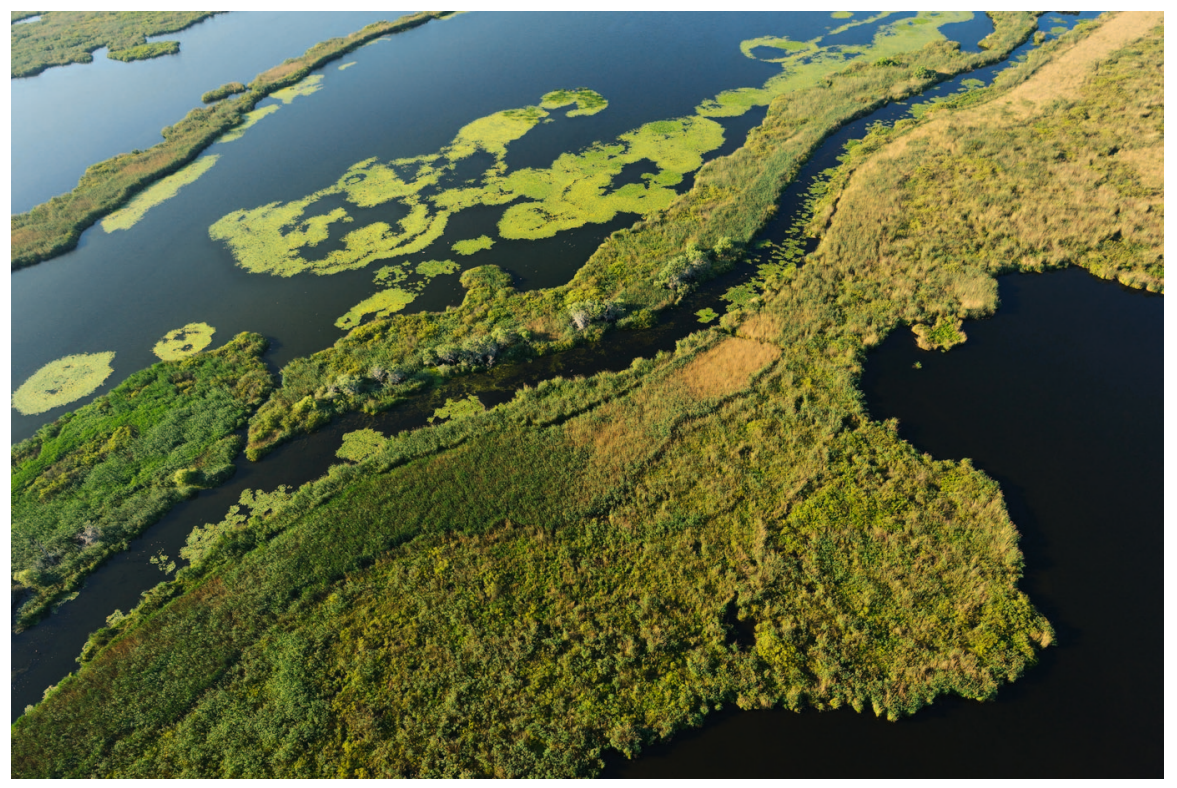

Fig. 9.7 The Danube delta, Europe's largest delta. (Photo credit: Staffan Widstrand/Rewilding Europe)

The unique Letea Forest mosaic savannah, situated in the Romanian section, is one of the few "primeval" forests of the country that has trees up to 700 years old. Through the designation as UNESCO Biosphere Reserves by both the Romanian and Ukrainian governments, with some relatively strictly protected core areas, the delta enjoys a high level of formal protection. Buffer areas and economic zones around these also provide opportunities for local developments without jeopardizing the natural values.

A lot of effort was spent the first year to ensure that the rewilding project is firmly anchored in two main communities in the outer and drier part of the delta, and with the relevant authorities at several levels. A key concept that should be tried in the Danube Delta is the development of one or two community wildlife conservan$\operatorname{cies}^{6}$, alongside with reintroduction of species, and with wildlife tourism providing income to these communities. This will allow for developing several different rewilding enterprises that start providing jobs and income to the people who live here.

To achieve this, geographical boundaries of the possible conservancies in Letea and Sfantu Georghe are identified in collaboration with local stakeholders. An inventory was made of the existing local businesses and other operating businesses in Sfantu Georghe, which is important information for the establishment of the community conservancy. Regular meetings for setting up a Community Conservancy in Sfantu Georghe and CA Rossetti municipalities brought mutual trust in and

\footnotetext{
${ }^{6}$ For an example, see the program of the Namibian Association of Community Based Natural Resource Management (http://www.nacso.org.na/).
} 
knowledge of the Rewilding Europe initiative. An MoU has been signed between the Danube Delta Biosphere Reserve Authority (DDBRA) and the local rewilding partner, WWF Romania, about the development of the rewilding area. Finally feasibility studies for the reintroduction of beaver and deer are subcontracted to ICAS, a research centre at the Brasov Wildlife Department. The deer release is in preparation.

\subsection{A Future Outlook for Rewilding Europe}

Rewilding Europe has presented a compelling vision about the historic opportunities that Europe is facing, and how we could make this a reality. With a mediaoutreach of more than 100 million people in the two first years, the initiative seems to capture the imagination of many Europeans (Schepers and Widstrand 2012). Support was received from all strands of society: local communities and governments, landowners, hunters, scientists, NGOs, EU Parliamentarians, local entrepreneurs and top business people. Practical work is starting: the first releases of key species, wildlife tourism developments, and small legal achievements. Nonetheless, most of the work is still in a stage of studying or negotiation with stakeholders. Between vision and practice there is a lot to do, and which needs a lot of support. The coming years will prove if Rewilding Europe can bridge the gap between vision and practice. 'Making it real' is therefore the slogan for the coming years.

Key for a successful continuation of the programme is a prosperous start of the several large scale projects that are on the way, such as the first European community conservancy in the Danube Delta (26,000 ha) and some agreements on better hunting practices in Velebit and Western Iberia, on a scale of tens of thousands of hectares, proving that the scale that Rewilding Europe is pursuing is not unrealistic. Just as important is a successful start up of some serious rewilding enterprises with a consistent spin-off, such as the European Safari Company and related enterprises in the rewilding areas, showing that an alternative rural economy can really be build in abandoned areas. Furthermore a careful selection of the next four pilot areas (completing the 'Rewilding 10 of Europe' objective in 2014) will help the initiative to illustrate that opportunities for rewilding exist in every corner of Europe.

Finally it's crucial to build on a strong relation between the local teams that do most of the work, and a central team that facilitates them in their rewilding, communication and enterprise activities. Rewilding Europe believes that real change can only come from ownership and leadership of those organizations and entities that nominated their areas to become part of the wider initiative.

Open Access This chapter is distributed under the terms of the Creative Commons Attribution Noncommercial License, which permits any noncommercial use, distribution, and reproduction in any medium, provided the original author(s) and source are credited. 


\section{References}

Burton, A. (2011). Where the wisents roam. Frontiers in Ecology and the Environment, 9(2), $140-140$.

Coleman, A., \& Aykroyd, T. (2009). Wild Europe and large natural habitat areas. (Conference Proceedings). Prague, Czech Republic.

Decker, S. E., Bath, A. J., Simms, A., Lindner, U., \& Reisinger, E. (2010). The return of the king or bringing snails to the garden? The human dimensions of a proposed restoration of European Bison (Bison bonasus) in Germany. Restoration Ecology, 18(1), 41-51. doi:10.1111/j.1526100X.2008.00467.x.

Deinet, S., Ieronymidou, C., McRae, L., Burfield, I. J., Foppen, R. P., Collen, B., \& Bohm, M. (2013). Wildlife comeback in Europe: The recovery of selected mammal and bird species. Final report to Rewilding Europe by ZSL, BirdLife International and the European Bird Census Council, London, UK.

EC. (2008). Poverty and social exclusion in rural areas (p. 243). European Commission-DG employment, social affairs and equal opportunities.

Enserink, M., \& Vogel, G. (2006). The carnivore comeback. Science, 314(5800), 746.

Geneletti, D., \& van Duren, I. (2008). Protected area zoning for conservation and use: A combination of spatial multicriteria and multiobjective evaluation. Landscape and Urban Planning, 85(2), 97-110.

Goderie, R., Helmer, W., Kerkdijk-Otten, H., \& Widstrand, S. (2013). The aurochs, born to be wild (p. 160). The Netherlands: Roodbont.

Hochtl, F., Lehringer, S., \& Konold, W. (2005). "Wilderness": What it means when it becomes a reality - a case study from the southwestern Alps. Landscape and Urban Planning, 70(1-2), 85-95. doi:10.1016/j.landurbplan.2003.10.006.

Keenleyside, C., \& Tucker, G. (2010). Farmland abandonment in the EU: An assessment of trends and prospects. WWF Netherlands and IEEP.

Kuemmerle, T., Perzanowski, K., Chaskovskyy, O., Ostapowicz, K., Halada, L., Bashta, A. T., \& Radeloff, V. C. (2010). European bison habitat in the Carpathian mountains. Biological Conservation, 143(4), 908-916.

Linnartz, L., \& Meissner, R. (2014). Rewilding horses in Europe. Background and guidelines-a living document. Rewilding Europe, The Netherlands.

Lupp, G., Höchtl, F., \& Wende, W. (2011). "Wilderness"-A designation for central European landscapes? Land Use Policy, 28(3), 594-603.

Pinto-Correia, T., \& Mascarenhas, J. (1999). Contribution to the extensification/intensification debate: New trends in the Portuguese montado. Landscape and Urban Planning, 46(1-3), $125-131$.

Russo, D. (2006). Effects of land abandonment on animal species in Europe: Conservation and management implications. Italy: UniversitÃ degli Studi de Napoli Federico, Napoli.

Sandom, C. J., Hughes, J., \& Macdonald, D. W. (2013). Rooting for Rewilding: Quantifying wild boar's sus scrofa rooting rate in the Scottish highlands. Restoration Ecology, 21(3), 329-335. doi:10.1111/j.1526-100X.2012.00904.x.

Schepers, F., \& Widstrand, S. (2012). Rewilding Europe: Annual review (p. 60). The Netherlands: Rewilding Europe.

Sylven, M., Wijnberg, B., Schepers, F., \& Teunissen, T. (2010). Rewilding Europe-Bringing the variety of life back to Europe's abandoned lands (p. 30). WWF.

Vlasakker, J. van de (2014). Bison Rewilding Plan 2014-2024. Rewilding Europe's contribution to the comeback of the European bison. The Netherlands.

Zhang, Z., Sherman, R., Yang, Z., Wu, R., Wang, W., Yin, M., \& Ou, X. (2013). Integrating a participatory process with a GIS-based multi-criteria decision analysis for protected area zoning in China. Journal for Nature Conservation, 21(4), 225-240. 